\title{
Peningkatan Kualitas Karya Ilmiah bagi Guru-guru Sekolah Dasar Negeri 3 Tejorejo, Kabupaten Kendal
}

\author{
Umbu Tagela ${ }^{1}$ \\ Heri Sanoto \\ Fakultas Keguruan dan Ilmu Pendidikan Universitas Kristen Satya Wacana
}

A R T I C L E I N F O

Article history:

Received 19-04-2021

Revised 22-04-2021

Accepted 26-04-2021

Key words:

Writing scientific papers, SDN teachers, Kendal Regency

\begin{abstract}
A B S T R A C T
The objectives of this community service activity: (1) increase teacher motivation in writing scientific papers and (2) increase the ability of teachers to write scientific papers in the form of research reports. This goal is achieved through training with the method of lectures, discussions, demonstrations, and exercises. After the training activities, monitoring and evaluation are carried out by the committee to see and assist teachers in writing scientific papers. The results show that the community service program is running well and smoothly. This program is able to motivate teachers to write scientific papers and improve the ability of teachers to conduct research and write research reports. Obstacles that arise at the research stage and the writing of the research results can be overcome by the mentoring method. As for suggestions, teachers are expected to have motivation and always cultivate scientific writing activities.
\end{abstract}
A B S T R A K
Tujuan aktivitas pengabdian masyarakat ini: (1) meningkatkan motivasi guru dalam menulis karya ilmiah dan (2) meningkatkan kemampuan guru dalam menulis karya ilmiah berupa laporan penelitian. Tujuan tersebut dicapai melalui pelatihan dengan metode ceramah, diskusi, demontrasi, dan latihan. Setelah aktivitas training dilaksanakan monitoring dan evaluasi oleh Panitia untuk melihat dan mendampingi guru dalam penulisan karya ilmiah. Hasilnya menunjukkan bahwa program pengabdian masyarakat berlangsung dengan baik dan lancar. Program ini mampu memberi motivasi kepada guru dalam menulis karya ilmiah dan mampu meningkatkan kemampuan guru dalam melakukan penelitian serta menulis laporan penelitian. Kendala-kendala yang muncul pada tahap penelitian dan penulisan hasil penelitian dapat diatasi dengan metode pendampingan. Adapun saran yang dapat diajukan bagi guru-guru diharapkan memiliki motivasi dan senantiasa membudayakan kegiatan menulis ilmiah. 


\section{PENDAHULUAN}

Undang-Undang Republik Indonesia Nomor 20 Tahun 2003 tentang Sistem Pendidikan Nasional, menyatakan bahwa jabatan guru sebagai pendidik merupakan jabatan profesional. Hal ini berarti, guru adalah jabatan profesi yang dituntut harus mampu melaksanakan tugasnya secara profesional. Seseorang dianggap profesional apabila mampu mengerjakan tugasnya dengan selalu berpegang teguh pada etika kerja, independen (bebas dari tekanan pihak luar), cepat (produktif), tepat (efektif), efisien dan inovatif serta didasarkan pada prinsip-prinsip pelayanan prima yang didasarkan pada unsur-unsur ilmu atau teori yang sistematis, kewenangan profesional, pengakuan masyarakat, dan kode etik yang regulative (Razak,1992).

Tagela (2017) mengatakan bahwa sudah sejak lama ditetapkan aturan pemerintah tentang pengembangan profesi guru. Dalam keputusan Menteri Negara pendayagunaan Aparatur Negara Nomor 84 tahun 1993 tanggal 24 Desember 1993 dinyatakan bahwa bidang kegiatan guru terdiri dari unsur utama yang terdiri atas kegiatan pada bidang pendidikan, proses belajar mengajar, dan pengembangan profesi, serta unsur penunjang. Peraturan Menteri Pendidikan Nasional Nomor 18 tahun 2007 tentang Sertifikasi Guru Dalam Jabatan, menyebutkan bahwa salah satu komponen yang dinilai dalam penilaian portofolio adalah karya pengembangan profesi.

Tujuan kegiatan pengembangan profesi guru adalah untuk meningkatkan mutu guru agar lebih profesional dalam melaksanakan tugas dan tanggung jawabnya. Jadi, kegiatan tersebut bertujuan untuk memperbanyak guru yang profesional, bukan untuk mempercepat atau memperlambat kenaikan pangkat/golongan. Selanjutnya, sebagai penghargaan kepada guru yang mampu meningkatkan mutu profesionalnya. Salah satu upaya peningkatan profesionalisme yang juga berhubungan dengan upaya kenaikan pangkat adalah menulis karya ilmiah. Permasalahan yang dihadapi para guru adalah penulisan karya ilmiah yang belum mumpuni.

Seperti dipaparkan sebelumnya bahwa salah satu cara meningkatkan profesionalisme adalah melalui penulisan karya ilmiah. Cara lain yang dapat ditempuh adalah dengan (1) menemukan teknologi dibidang pendidikan, (2) membuat alat pelajaran/alat peraga atau alat bimbingan, dan (3) mengikuti kegiatan pengembangan kurikulum (Depdiknas, 2001). Dari cara-cara tersebut, menulis karya ilmiah bagi kebanyakan guru termasuk guru SD merupakan kegiatan yang masih sulit dilakukan sehingga perlu adanya banyak bimbingan (Sumardi, 2011).

Pada umumnya guru masih banyak yang kesulitan naik pangkat dan golongan dari IV a/Pembina ke IV b/ Pembina tingkat I, yang kendalanya adalah pembuatan karya ilmiah tulis yang disyaratkan harus dipenuhi angka kredit minimal 12 dari unsur pengembangan profesi yang antara lain meliputi melakukan kegiatan karya tulis atau karya ilmiah dalam bidang pendidikan. Belakangan ini kesulitan makin dirasakan oleh guru yang berpangkat lebih rendah dengan Keputusan Menteri No. 16 tahun 2009 tentang karya tulis ilmiah yang sudah menjadi syarat kenaikan dari golongan III b ke III c. Oleh karena itu, pelatihan penulisan karya ilmiah bagi guru, terutama guru SD begitu diperlukan. Dari hasil pembincangan dengan guru-guru SD yang bergolongan III b dan IV a di SDN 3 Tejorejo, tergambar bahwa hampir semua guru mengalami kendala dalam penulisan karya ilmiah terutama berupa laporan penelitian. Oleh karena 
itu, pelatihan penulisan karya ilmiah ini akan ditujukan kepada guru-guru SDN 3 Tejorejo di Kabupaten Kendal.

Kegelisahan yang dialami oleh guru SD, dalam hal ini guru SDN 3 Tejorejo, dalam membuat karya ilmiah yang disebabkan oleh masih rendahnya kemampuan guru dalam menulis karya ilmiah (Suparno, 2005). Kegelisahan ini terjadi karena salah satu hal yang harus dimiliki untuk dapat naik pangkat adalah karya ilmiah. Walaupun demikian, motivasi guru dalam menulis karya ilmiah masih rendah. Karya ilmiah dipandang sebagai hal yang sulit dilakukan atau dibuat. Guru cenderung mengecap dirinya tidak mampu melakukannnya. Keadaan ini tentunya sangat disayangkan, oleh karena itu sudah sepatutnya motivasi dan pemahaman guru mengenai karya tulis ilmiah diangkat. Salah satu cara yang dapat dilakukan adalah melalui pelatihan penulisan karya ilmiah kepada guru-guru SDN 3 Tejorejo di Kabupaten Kendal.

\section{METODE PELAKSANAAN}

Pelatihan yang diangkat dalam kegiatan pengabdian pada masyarakat ini bertujuan meningkatkan motivasi dan kemampuan menulis karya ilmiah bagi guru SDN 3 di Telojorejo, Kabupaten Kendal. Atas dasar itu, diusulkan kerangka pemecahan masalah secara operasional sebagai berikut.

1) Penyelenggaraan pelatihan intensif tentang:

a) Peluang dan manfaat penulisan karya ilmiah berupa laporan penelitian

b) Penulisan karya ilmiah berupa laporan penelitian mencangkup:

1) Teknik mengidentifikasi, memilih dan merumuskan topik/judul karya tulis ilmiah.

2) Teknik menyusun kerangka tulisan karya ilmiah.

3) Teknik mengumpulkan bahan-bahan tulisan, mengorganisasikan, dan mengkonsep karya tulis ilmiah, dan

4) Teknik menulis dan menyunting karya ilmiah.

2) Aplikasi tentang berbagai hal yang telah dipelajari dari pelatihan dengan pendampingan dan supervisi dari tim pengabdian masyarakat (Atmowiloto, 2001). Sasaran dari pengabdian masyarakat ini adalah guru Sekolah Dasar Negeri 3 di Tejorejo Kabupaten Kendal. Sasaran ini ditujukan untuk 12 orang guru SD negeri maupun swasta. Kegiatan Pengabdian masyarakat penulisan karya ilmiah ini diselenggarakan dengan melibatkan berbagai pihak. Pihak-pihak yang terlibat, yaitu: (1) Kepala SDN 3 Tejorejo Kabupaten Kendal yang berperan dalam pemberian izin, sosialisasi kegiatan kepada sasaran, dan pendaftaran anggota pelatihan, (2) Dosen FKIP sebanyak dua orang yang berperan sebagai narasumber (tutor) dalam pelatihan, (3) guru-guru SDN sebanyak 11 orang di Kecamatan Tejorejo sebagai peserta pelatihan, dan (4) Panitia pelaksana kegiatan yang berperan dalam perencanaan, pelaksanaan, dan refleksi kegiatan.

Metode pembelajaran yang digunakan untuk mendukung keberhasilan program antara lain sebagai berikut:

a. Ceramah dan diskusi 
Metode ini dipilih untuk membangkitkan motivasi guru dalam menulis karya ilmiah dan mejelaskan materi yang bersifat teoritik terkait dengan peraturan perundangan yang menyangkut kenaikan pangkat dan angka kredit. Selain itu juga membahas bermacam-macam karya tulis ilmiah termasuk laporan penelitian tindakan kelas.

b. Demonstrasi

Metode ini dipilih untuk menjelaskan sesuatu proses kerja secara bertahap sehingga dapat memberi kemudahan bagi peserta dapat mengamati secara cermat proses pembuatan karya tulis ilmiah dari pesiapan sampai penyuntingan naskah.

c. Latihan/Praktik atau tutorial

Pada metode ini peserta mempraktikan pembuatan karya tulis ilmiah dengan bimbingn pelatihan sehingga peserta dapat membuat karya tulis ilmiah dengan baik.

Untuk mengetahui keberhasilan kegiatan ini, dilakukan dengan melihat keterlibatan dan antusias peserta. Keterlibatan peserta dapat dilihat dari absen peserta kegiatan dan antusiasme peserta dilihat dari motivasi peserta selama kegiatan berlangsung. Digunakan juga metode angket/kuesioner untuk mengumpulkan data mengenai respons guru terhadap pelaksanaan pelatihan. Setelah kegiatan pelatihan dilaksanakan monitoring dan evauasi oleh panitia pelaksana untuk melihat dan mendampingi guru dalam menulis karya ilmiah.

\section{HASIL DAN PEMBAHASAN}

Pelaksanaan kegiatan pelatihan ini membutuhkan waktu secara menyeluruh selama 6 (enam) bulan. Kegiatan pengabdian masyarakat pelatihan penulisan karya ilmiah ini yang direncanakan dilaksanakan pada minggu ketiga di bulan Maret 2020. Setelah berkoordinasi dengan pihak Kepala SDN 3 Tejorejo, akhirnya kegiatan dapat terlaksana pada Sabtu, 28 Maret 2020. Kegiatan Pengabdian masyarakat yang semula di targetkan 11 orang guru mengalami penambahan kuota sehingga mencapai 12 orang. Hal ini sesuai dengan hasil diskusi dengn pihak Kepala SDN 3 Tejorejo. Alasan karena ada 1 orang guru dari SD lain yang ingin sekali mengikuti kegiatan ini. Pelatihan penulisan karya ilmiah bagi guru-guru SDN 3 Tejorejo dilaksanakan atas kerja sama dengan Kepala SDN 3 Tejorejo dan bertempat di SDN 3 Tejorejo Kabupaten Kendal. Pelatihan ini diisi oleh dua orang narasumber dari FKIP-UKSW.

Ada beberapa hal yang patut dibahas dari hasil penelitian yang telah dilaksanakan. Pertama berkaitan dengan motivasi guru, motivasi guru yang semula dipandang kurang dalam hal menulis karya ilmiah dapat dibangkitkan oleh narasumber setelah diberikan gambaran-gambaran tentang peran penting kegiatan penulisan karya ilmiah bagi guru-guru. Semangat guru makin terlihat ketika disinggung hubungan antara kenaikan pangkat dan budaya menulis ilmiah.

Kedua yang perlu dibahas adalah antusiasi guru untuk mengikuti pelatihan. Setelah memberi motivasi oleh narasumber I, para guru terlihat antusias dalam menyimak dan berdiskusi ketika narasumber II berbagi pengalaman mengenai menulis karya ilmiah. Setelah dilakukannya wawancara, antusiame ini disebabkan oleh berbagai alasan, seperti keinginan guru untuk meningkatkan profesionalisme, terutama 
dalam melaksanakan penelitian tindakan kelas, keinginan bisa menulis proposal dan hasil penelitian, serta alasan terbanyak adalah keinginan untuk mempersiapkan diri untuk bisa naik golongan/pangkat. Namun, ada sedikit rasa kurang puas dari para guru lantaran kegiatan menulis karya ilmiah ini hanya dilaksanakan dalam waktu satu hari. Padahal guru-guru ingin mendapatkan bimbingan secara intensif, terutama dalam hal melakukan penelitian tindakan kelas. Baik tahap penulisan maupun tahap pelaksanaan kegiatan.

Rasa tidak puas peserta hilang ketika panitia dan narasumber menjelaskan setelah pelatihan, dilaksanakan pendampingan terhadap guru-guru dalam melaksanakan penelitian dan penulisan karya ilmiah. Bahkan ketua panitia merangkap nara sumber, yaitu bapak Dr. Umbu Tagela, M.Si., sampai berkali-kali mengulangi pernyataan pelaksanaan pendampingan untuk menyakinkan peserta kegiatan.

Ketiga hal yang perlu mendapatkan perhatian adalah kendala yang dialami oleh guru ketika sesi pelatihan mengidentifikasi masalah dalam pelatihan tentang penelitian tindakan kelas. Guru-guru terlihat kesulitan mengidentifikasi masalah yang dimiliki. Namun setelah pendampingan yang dilakukan dengan melibatkan narasumber dan panitia pelaksana, kesulitan ini dapat diatasi. Guru-guru terlihat begitu bersemangat untuk saling menyampaikan masalah yang dimiliki dan rekaan solusi yang ditawarkan untuk mengatasi masalah yang dihadapi. Guru-guru kemudian berusaha menyusun draf proposal penelitian tindakan kelas dengan pendampingan narasumber dan panitia pelaksana. Draf tersebutlah yang dikembangkan oleh guru setelah kegiatan pelatihan dan dilanjutkan dengan pelaksanaan penelitian dan penulisan laporan hasil penelitian.

\section{SIMPULAN}

Adapun simpulan yang dapat ditarik setelah pelaksanaan pengabdian masyarakat penulisan karya ilmiah ini adalah sebagai berikut:

1. Program pengabdian masyarakat berjalan secara baik dan lancar. Program ini mampu meningkatkan motivasi guru SDN 3 Tejorejo Kabupaten Kendal dalam menulis karya ilmiah.

2. Program pengabdian masyarakat yang diselenggarakan mampu meningkatkan kemampuan guru SDN 3 Tejorejo Kabupaten Kendal dalam menulis karya ilmiah berupa laporan penelitian kemampuan yang dimaksud meliputi:

a. Kemampuan mengidentifikasi, memilih dan merumuskan topik dan judul

b. Kemampuan menyusun kerangka tulisan (outline)

c. Kemampuan mengumpulkan bahan-bahan tulisan, mengorganisasikan, dan mengkonsep tulisan.

d. Kemampuan menulis ilmiah dan menyunting

Kegiatan pengabdian masyarakat ini mampu meningkatkan motivasi guru dalam menulis karya ilmiah. Kegiatan penelitian ini juga mampu meingkatkan pemahaman guru SDN 3 Tejorejo Kabupaten Kendal tentang penulisan karya ilmiah. Guru-guru memiliki semangat untuk melakukan penelitian tindakan kelas dan menulisnya dalam bentuk laporan penelitian.

\section{DAFTAR PUSTAKA}


Atmowiloto, A. 2001, Mengarang itu Gampang, Jakarta, Gramedia

Depdiknas. 2001. Pedoman Penyusunan Karya Tulis Ilmiah di Bidang Pendidikan dan Angka Kredit Pengembangan Profesi Guru. Jakarta: Depdiknas Dirjen Dikdasmen Direktorat Tenaga Kependidikan.

Djuroto, Totok dan Bambang Suprijadi. 2005. Menulis Artikel dan Karya Ilmiah. Bandung : PT Remaja Roskadarya.

Martono, Nanang. "Menulis Artikel dalam Jurnal Ilmiah". Dalam http://nanangmartono.blog.unsoed.ac.id/files/2012/07/menulis-karya-Ilmiah-untukSkripsi1.pdf. diakses 7 Februari 2013.

Prayitno, Harun Joko dkk. (ed). 2000. Pembudayaan Penulisan Karya Ilmiah. Surakarta: Muhammadiyah Universitas Press.

Razak, A. 1992, Kalimat efektif, Struktur, Gaya dan Variasi, Jakarta, Gramedia.

Suparno, 2005, Pedoman menjadi Penulis (riset, observasi, penelitian, Jakarta, Restu Agung.

Tagela, Umbu, 2017, Menulis Karya Ilmiah, Salatiga, Widyasari Press.

Undang-undang Republik Indonesia Nomor 20 Tahun 2003 tentang Sistem Pendidikan Nasional. 2003. Jakarta:Depdiknas. 


\section{LAMPIRAN}
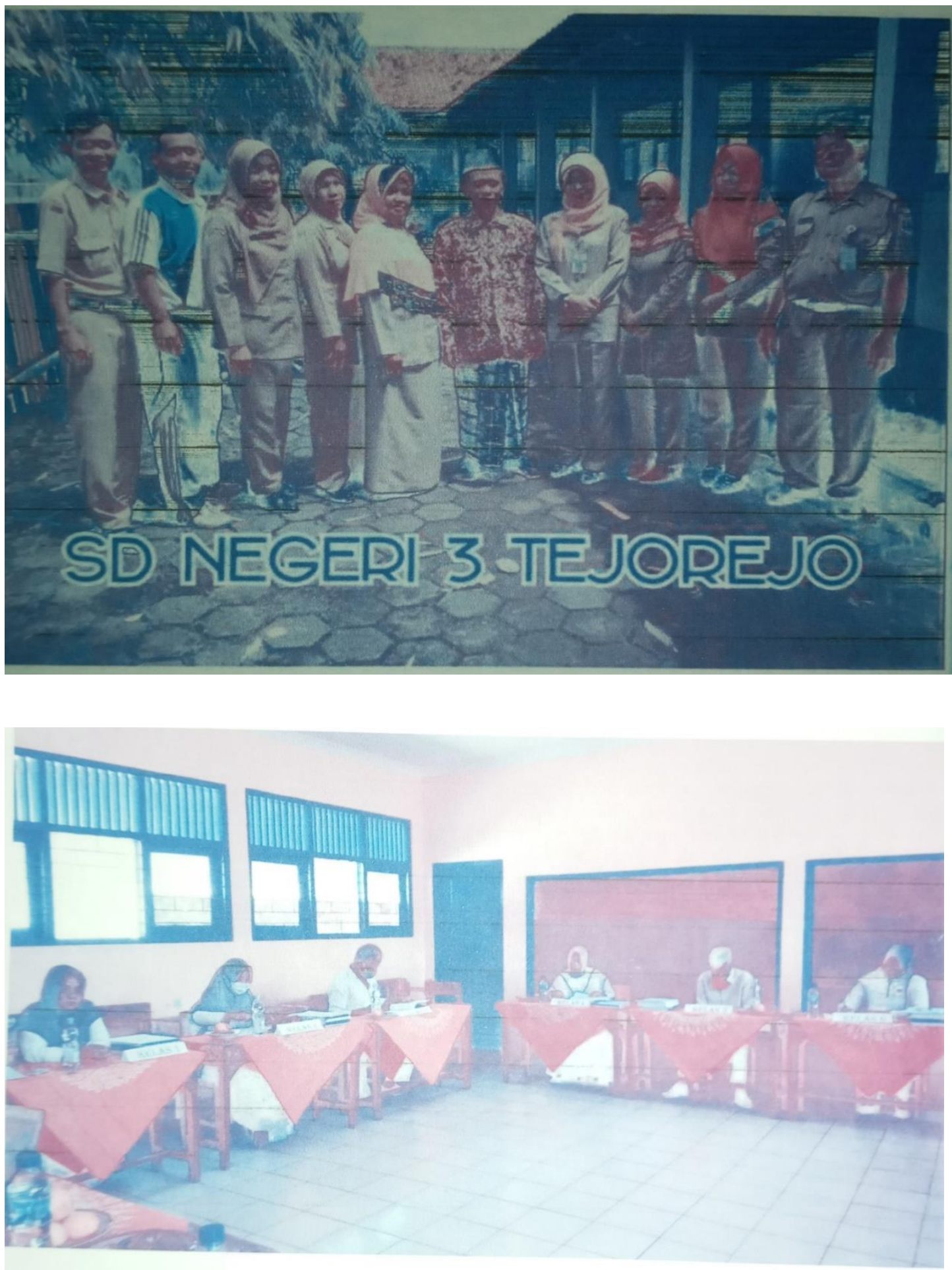